\title{
Adapt or Perish? How Parties Respond to Party System Saturation in 21 Western Democracies, 1945-2011 - CORRIGENDUM
}

Marc van de Wardt and Arjen van Witteloostuijn

doi:10.1017/S0007123419000152, Published by Cambridge University Press, 23 August 2019.

The authors apologise for the misspelling of Arjen van Witteloostuijn's affiliation in their article. It should read as follows:

Vrije Universiteit Amsterdam

\section{Reference}

van de Wardt M and van Witteloostuijn A (2019) Adapt or Perish? How Parties Respond to Party System Saturation in 21 Western Democracies, 1945-2011. British Journal of Political Science. Published by Cambridge University Press, 23 August 2019. doi:10.1017/S0007123419000152

Cite this article: van de Wardt M, van Witteloostuijn A (2021). Adapt or Perish? How Parties Respond to Party System Saturation in 21 Western Democracies, 1945-2011 - CORRIGENDUM. British Journal of Political Science 51, 39-39. https://doi.org/10.1017/S0007123419000565

(C) Cambridge University Press 2019. This is an Open Access article, distributed under the terms of the Creative Commons Attribution licence (http://creativecommons.org/licenses/by/4.0/), which permits unrestricted re-use, distribution, and reproduction in any medium, provided the original work is properly cited. 